\title{
Correction to: Remediation Through Transformation: Applying Educational Theory to the Struggling Resident
}

Benjamin Vipler, MD ${ }^{1,2}$ (D) Jennifer McCall-Hosenfeld, MD, MS ${ }^{1,2}$, and Paul Haidet, MD, $\mathrm{MPH}^{1,2}$

'Division of General Internal Medicine, Penn State Milton S. Hershey Medical Center, Hershey, PA, USA; ${ }^{2}$ Penn State College of Medicine, Hershey, PA, USA

$\mathrm{J}$ Gen Intern Med

DOI: $10.1007 / \mathrm{s} 11606-020-06326-8$

(c) Society of General Internal Medicine 2020

C ORRECTION TO: J GEN INTERN MED

https://doi.org/10.1007/s11606-020-06036-1

There were problems with the pdf display of this paper. It has been republished with correction.

Corresponding Author: Benjamin Vipler, MD; Division of General Internal Medicine, Penn State Milton S. Hershey Medical Center, Hershey, PA, USA (e-mail: bvipler@pennstatehealth.psu.edu).

Publisher's Note: Springer Nature remains neutral with regard to jurisdictional claims in published maps and institutional affiliations. 